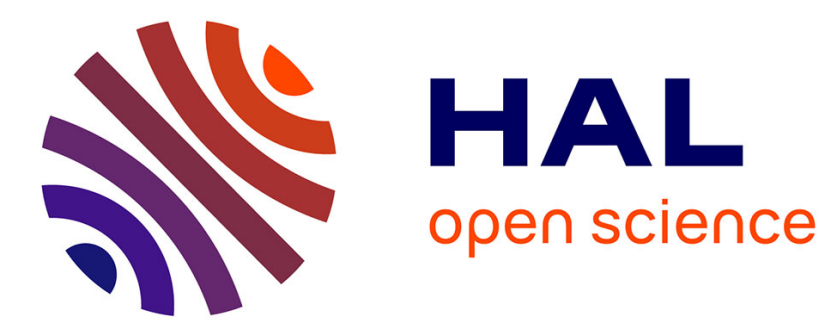

\title{
Phosphatidylcholine/sphingomyelin metabolism crosstalk inside the nucleus
}

Elisabetta Albi, Remo Lazzarini, Mariapia Viola Magni

\section{To cite this version:}

Elisabetta Albi, Remo Lazzarini, Mariapia Viola Magni. Phosphatidylcholine/sphingomyelin metabolism crosstalk inside the nucleus. Biochemical Journal, 2008, 410 (2), pp.381-389. 10.1042/BJ20070758 . hal-00478820

\section{HAL Id: hal-00478820 https://hal.science/hal-00478820}

Submitted on 30 Apr 2010

HAL is a multi-disciplinary open access archive for the deposit and dissemination of scientific research documents, whether they are published or not. The documents may come from teaching and research institutions in France or abroad, or from public or private research centers.
L'archive ouverte pluridisciplinaire HAL, est destinée au dépôt et à la diffusion de documents scientifiques de niveau recherche, publiés ou non, émanant des établissements d'enseignement et de recherche français ou étrangers, des laboratoires publics ou privés. 


\title{
PHOSPHATIDYLCHOLINE/SPHINGOMYELIN METABOLISM CROSSTALK INSIDE
} THE NUCLEUS

\author{
Albi Elisabetta, Lazzarini Remo and Viola Magni Mariapia
}

Department of Clinical and Experimental Medicine, Physiopathology, Policlinico Monteluce, University of Perugia, 06100 Perugia, Italy,

Short title: Nuclear Phosphatidylcholine/Sphingomyelin Relationship

Correspondence to: Elisabetta Albi, Department of Clinical and Experimental Medicine, Physiopathology, Policlinico Monteluce, Via Brunamonti - 06100 Perugia, Italy. Tel 0039075-5724937 Fax:0039-075-5726803,e-mail: ealbi@unipg.it

Abbreviations: DAG, diacylglycerol; PC, phosphatidylcholine; PC-PLC, phosphatidylcholine-specific phospholipase C; PL, phospholipid; PPC, phosphocholine; SM, sphingomyelin, N-SMase, neutral-sphingomyelinase; SM-synthase sphingomyelin-syntase; RSM-synthase, reverse sphingomyelin-synthase. 


\section{Synopsis}

It is known that the phospholipids represent a "minor component" of chromatin. Recently it has been highlighted that these lipids are metabolised directly inside the nucleus thanks to the presence of the enzymes related to their metabolism such as neutral sphingomyelinase, sphingomyelin-synthase, reverse sphingomyelin-synthase and phosphatidylcholine-specific phospholipase C. The chromatin enzymatic activities change during cell proliferation, differentiation and/or apoptosis independently of the enzyme activities present in the nuclear membrane, microsomes or cell membranes. The present research was aimed to investigate the crosstalk of the lipid metabolisms in nuclear membrane and chromatin isolated from rat liver in vitro and in vivo. The effect of neutral-sphingomyelinase activity on phosphatidylcholinespecific phospholipase $\mathrm{C}$ and sphingomyelin-synthase, which enrich the intranuclear diacylglycerol pool and the effect of phosphatidylcholine-specific phospholipase $\mathrm{C}$ activity on neutral sphingomyelinase and reverse sphingomyelin-synthase, which enrich the intranuclear ceramide pool, were investigated. The results show that in chromatin exists a phosphatidylcholine/sphingomyelin metabolism crosstalk which regulates the intranuclear ceramide/diacylglycerol pool. Its specificity was demonstrated by D609 inhibitor effect. The chromatin lipid metabolism is activated in vivo during cell proliferation indicating that it could play a role on cell function. The possible mechanism of the crosstalk was discussed considering the recent literature in the field.

Keywords: ceramide, chromatin, diacylglycerol, nuclear membrane, sphingomyelin. 
Introduction

The involvement of sphingomyelin (SM) and phosphatidylcholine (PC) in signal transduction $[1,2]$ and the role of diacylglycerol (DAG) and ceramides in cell proliferation, differentiation and apoptosis have been widely described [3-5]. SM is metabolised by sphingomyelinase (SMase) producing ceramide and phosphocholine (PPC) [6] and by reverse-sphingomyelin-synthase (RSM-synthase) that synthesises PC using DAG and PPC group of SM, freeing ceramide [7]. Phosphatidylcholine-specific phospholipase C (PC-PLC) degrades PC producing DAG and PPC [8] whereas sphingomyelin-synthase (SM-synthase) synthesises SM using ceramide and PPC group of PC, freeing DAG [9]. It is known that PC breakdown activates PKC [10], a family of serine/threonine kinases which participates in signal transduction of many cells and mediates a wide number of intracellular functions [11]. On the other hand it has been demonstrated that cellular DAG may activate the SMase with consequent inactivation of PKC [12] whereas the activation of SM-synthase causes an increase of DAG with positive effect on this enzyme [13]. The co-operation between different lipid pathways has been also reported in cells stimulated with TNF $\alpha$. In fact, TNF $\alpha$ acts on NF-kB through an initial activation of PC-PLC with production of DAG which in turn stimulates SMase activity with consequent ceramide formation and specific kinase isoform activation [14]. Moreover it has been demonstrated that cellular SMase and SMsynthase are involved in cell proliferation [15] and apoptosis process [16] respectively. During the last then years many evidences highlighted the presence of a phospholipids (PLs) fraction in the nucleus that changes in relation to cell function [17-20]. These lipids change thanks to the existence of neutral-SMase (N-SMase) [21-26], SM-synthase [27, 28], PC-PLC $[29,30]$, and RSM-synthase [31] activity in the nucleus. The nuclear N-SMase activity is involved in cell proliferation [32] and/or apoptosis [33]. The purification of the subnuclear fractions has permitted to demonstrate that the enzymes localised in the chromatin have different $\mathrm{pH}$ optimum and $\mathrm{Km}$ from those present in nuclear membrane [25, 27, 29, 31]. At the moment the nuclear membrane and chromatin enzymes have not been purified and characterised and therefore do not exist specific antibodies that could be used for the study of their exact localization. Nevertheless, an electron microscopy analysis on the rat liver sections performed by using N-SMase conjugated with colloidal gold particles showed that the SM is present in nuclear domains active in DNA replication, transcription and probably also in different steps of mRNA processing (data not shown). In the other hand the SM, NSMase and SM-synthase activity have been recently demonstrated in an intranuclear 
complex containing STAT3 and a new-synthesised double-strand RNA, supporting their association with the active chromatin [34]. Moreover N-SMase activity plays various roles in different subnuclear fractions. In fact, during cell proliferation induced by partial hepatectomy, the activation of the enzyme present in nuclear membrane changes the level of SM and cholesterol (CHO) [35] modifying the fluidity and the size of the pores [36] and consequently regulating the mRNA nucleus-cytoplasm efflux [37]. In the same experimental conditions, the chromatin N-SMase is involved in the DNA structure modification and in the molecular events that occur during the beginning of the S-phase of the cell cycle [25]. These results were supported in a study in which the ciprofibrate treatment induced liver cell proliferation and the drug withdrawal stimulated the cells to apoptosis [38]. The authors have shown that the chromatin N-SMase activity increases during cell proliferation when the SMsynthase activity is depressed whereas the chromatin SM content increases during apoptosis as a consequence of SM-synthase activation [38]. It has been supposed that a decrease in SM may favour the opening of the helix during DNA synthesis whereas the increase of the SM amount may hinder the DNA duplication. Since these results suggested strongly that modifications of intranuclear lipid metabolism occur in relation to cell life, it was possible to hypothesise the existence of a lipid metabolic machinery that takes place inside the nucleus. In order to investigate about this hypothesis, the aim of the present research was to study the crosstalk between SM and PC metabolism inside the nucleus either in vitro or in vivo during liver regeneration. 
Experimental Procedures

Materials -The radioactive SM (choline-methyl $\left.{ }^{14} \mathrm{C}, 54.5 \mathrm{Ci} / \mathrm{mol}\right)$ and PC (L-3-phosphatidyl $\mathrm{N}$-methyl- ${ }^{3} \mathrm{H}$ choline 1,2 dipalmitoyl, $81.0 \mathrm{Ci} / \mathrm{mmol}$ ) and ${ }^{3} \mathrm{H}-\mathrm{UTP}$ were from Amersham Pharmacia Biotech (Rainham, Essex, UK); GF/C filters were from Whatman (Maidstone, Kent, UK). HionicFluor and Econofluor were from PerkinElmer (Waltham, Massachusetts, USA) and Ecoscint $A$ and Filtron-X were from National Diagnostic (Atlanta, Georgia, U.S.A.). PC, SM, ceramides, diacylglycerol and O-Tricyclodec-9-yl ditiocarbonate potassium salt (D609), phenylmethylsulfonylfluoride (PMSF), ethylendiaminetetracetic acid (EDTA) and RNA polymerase were from Sigma Chemical Co. (St. Louis, Missouri, U.S.A.)

Animals - Thirty day old Sprague Dawley rats of either sex (Harlan Nossan, Milano, Italy) were used. They were kept at a normal light-dark period and had free access to pelleted food and water. The animals were laparatomized after anaesthesia with $100 \mathrm{mg} / \mathrm{Kg}$ Farmotal (Farmitalia, Italy), the liver was perfused via the portal vein with cold $0.25 \mathrm{M}$ sucrose, $3.3 \mathrm{mM}$ $\mathrm{CaCl}_{2}, 1.0 \mathrm{mM}$ PMSF solution at $\mathrm{pH} 7.2$ and immediately removed. The animals were killed by cervical dislocation. Liver regeneration was induced by hepatectomy which stimulates liver cells to proliferate. Hepatectomy was performed, after anesthesia, between 8-10 a.m. as previously reported [39]. Sham operated animals were used as controls. The animals were killed at different times after operation from 0 to 24 hours. All treatments were made according to the international regulation of National Institutes of Health.

Nuclear membrane and Chromatin purification - Nuclear membrane and chromatin were isolated and purified as previously described [31]. For chromatin extraction, purified hepatocyte nuclei were gently suspended for $5 \mathrm{~min}$ in $10 \mathrm{mM}$ Tris containing $0.25 \mathrm{M}$ sucrose $1 \mathrm{mM}$ PMSF, $0.3 \%$ Triton X-100 adjusted to $\mathrm{pH} 7.4$ with $0.1 \mathrm{~N} \mathrm{NaOH}$ and centrifuged at 5000 $\mathrm{g}$ for $5 \mathrm{~min}$ in order to remove the outer nuclear membrane. Subsequent four washings of the preparation with hypotonic solution containing $0.075 \mathrm{M} \mathrm{NaCl}, 0.024 \mathrm{M}$ EDTA and $1 \mathrm{mM}$ PMSF pH 8.0 resulted in the swelling of the nuclei and destruction of inner nuclear membrane. The chromatin extraction was completed by washing the denuded nuclei in progressively less concentrated Tris solutions $(50 \mathrm{mM}, 10 \mathrm{mM}, 2 \mathrm{mM}$ and $0.4 \mathrm{mM})$ containing $1 \mathrm{mM}$ PMSF, $\mathrm{pH}$ 8.0. After each washing, the material was recovered by centrifugation at $8000 \mathrm{~g}$ for $10 \mathrm{~min}$ and it was re-suspended each time with 1-3 strokes of the pestle at low 
velocity. Two washings for each solution were made. Finally the material was re-suspended in 1mM PMSF (a protease inhibitor) brought to $\mathrm{pH} 8$ with ammonium hydroxide and stirred overnight at $4{ }^{\circ} \mathrm{C}$. The solution was then centrifuged at $90000 \mathrm{~g}$ for $30 \mathrm{~min}$. The chromatin containing sediment was re-suspended in $10 \mathrm{mM}$ Tris + $1 \mathrm{mM}$ PMSF, pH 8.6.

Transcriptional activity of the chromatin - The chromatin transcription was evaluated according to Gould et al. [40] with the following modifications. The DNA content was evaluated at $260 \mathrm{~nm}$. Purified chromatin, corresponding to $20 \mu \mathrm{g}$ DNA, was incubated with 10mM Tris pH 8.0, 25mM $\mathrm{MnCl}_{2}, 150 \mathrm{mM} \beta$-mercaptoetanol, $6 \mathrm{mM}$ ATP, 6mM CTP, $6 \mathrm{mM}$ GTP, $3 \mathrm{mM}$ mercuriuridine, $20 \mu \mathrm{l}^{3} \mathrm{H}$-uridine and $6 \mu \mathrm{l}$ RNA polymerase to a final volume of $250 \mu 1$. Incubation was performed at $37{ }^{\circ} \mathrm{C}$ for different time until four hours and it was stopped by adding cold $10 \mathrm{mM}$ Tris and 10\% TCA (final concentration). Suspension was filtered with GF/C Wathman filter and it was washed six time with $8 \%$ TCA until no radioactivity was recovered in the filtered solution. The radioactivity was measured in counting vials containing $10 \mathrm{ml}$ of HionicFluor with a liquid scintillation analyzer (1500 TRICarb) Packard Instrument Company, Meriden, USA. The filter was dried by phone and treated in the counting vials containing $0.5 \mathrm{ml}$ Filtron-X at $60^{\circ} \mathrm{C}$ for $30 \mathrm{~min}$. When the filter became cold, $20 \mu \mathrm{l}$ of acetic acid and $10 \mathrm{ml}$ of Econofluor were added. The radioactivity was measured as above reported and it was referred to RNA content [41]. Chromatin transcriptional activity was also evaluated after $60^{\prime}$ and $90^{\prime}$ ' of treatment necessary for the PCSM metabolism study as described below in "experiment 1 " and "experiment 2" (cold molecules were used at the same concentration of those labelled).

Lipid analysis - Lipids were extracted from nuclear membrane and chromatin; SM and PC were separated on thin layer silica gel chromatography (TLC), identified in relation to the standard and scraped into test tubes for inorganic phosphorous determination [31]. Ceramide was separated according to Previati et al. [42] on bidimensional TLC by using chloroform/methanol/acetic acid, 190:9:1 (v/v) and diethyl ether/acetic acid, 100:1 (v/v) as first and second mobile phase respectively. The spot, identified in relation to the standard, was scraped and eluted by two washing with chloroform/methanol $(2: 1)$. The ceramide was dried and dissolved in $20 \mu 1$ pyridine; then $40 \mu 1$ benzoyl chloride were added. The sample was heated $1 \mathrm{~h}$ at $60^{\circ} \mathrm{C}$ and the solution was evaporated under an efficient fume hood. $4 \mathrm{ml}$ methanol were added and the sample was heated again $1 \mathrm{~h}$ at $70^{\circ} \mathrm{C}$. After methanol 
evaporation, $1 \mathrm{ml}$ hexane and $1 \mathrm{ml} \mathrm{Na} \mathrm{CO}_{3}$ saturated methanol solution was added. The sample was centrifuged at low speed. The lower phase was washed first with $1 \mathrm{ml}$ methanol containing $0.6 \mathrm{HCl}$ and then with pure methanol. The lower phase was evaporated and the residue was dissolved in a known volume of hexane for the analysis by HPLC with a column Lichrosorb Si 60 from Merck (125 x $4 \mathrm{~mm}, 5 \mu \mathrm{m})$ and, as mobile phase, hexane/2-propanol (98:2, v/v, flow rate: $0.5 \mathrm{ml} / \mathrm{min}$ ) and it was measured at $240 \mathrm{~nm}$. The DAG was derivatized directly in the lipid extract by using Naproxen as a fluorescent label [43] and it was purified by TLC using petroleum hexane/diethyl ether $(75: 25, \mathrm{v} / \mathrm{v})$ as mobile phase. The spot, identified in relation to the standard, was scraped and eluted by two washing with $2 \mathrm{ml}$ of acetonitrile. The analysis by HPLC was performed with a column Lichrospher RP18 from Merck (250 x $4.6 \mathrm{~mm}, 5 \mu \mathrm{m})$ using, as mobile phase, acetonitrile/iso-propanol (90:10, v/v, flow rate of $1.5 \mathrm{ml} / \mathrm{min}$ ) and the fluorescence was detected (exc: $230 \mathrm{~nm}$, em: $352 \mathrm{~nm}$ ). The total ceramide and DAG content was estimated by the measurement of the area of all identified peaks.

\section{Phosphatidylcholine-sphingomyelin metabolism}

The experimental plan is below reported (Fig.1)

Experiment 1. Effect of nuclear membrane or chromatin endogenous N-SMase on PC-PLC and SM-synthase activities - $1 \mathrm{nmol}$ of $\left[{ }^{14} \mathrm{C}\right]-\mathrm{SM}$ was diluted by adding $49 \mathrm{nmol}$ cold SM to a final radioactivity of $1.08 \mathrm{Ci} / \mathrm{mol}$. The preincubation was performed for $60 \mathrm{~min}$ at $37{ }^{\circ} \mathrm{C}$ with a reaction mixture containing $0.1 \mathrm{M}$ Tris $/ \mathrm{HCl} \mathrm{pH} 7.6$ or 8.4 for nuclear membrane or chromatin respectively, $6 \mathrm{mM} \mathrm{MgCl}_{2}, 0.1 \%$ Triton $\mathrm{X}-100,0.1 \mathrm{mM}{ }^{14} \mathrm{C}-\mathrm{SM}$ and sample suspension in $10 \mathrm{mM}$ Tris $+1 \mathrm{mM}$ PMSF $(\mathrm{pH} 7.6$ and $\mathrm{pH} 8.4$ for nuclear membrane and chromatin respectively) equivalent to $200 \mu \mathrm{g}$ protein, to a final volume of $0.2 \mathrm{ml}$. In the control sample, the preincubation was performed without ${ }^{14} \mathrm{C}$-SM. At the end of the preincubation, considered 0 ' time, $0.1 \mathrm{mM}{ }^{14} \mathrm{C}-\mathrm{SM}+0.3 \mathrm{mM}{ }^{3} \mathrm{H}-\mathrm{PC}, 0.1 \mathrm{mM}$ ceramide, 80 $\mu \mathrm{g} / \mathrm{ml}$ Na-taurodeoxycholate and $2 \mathrm{mM} \mathrm{CaCl}_{2}$ were added to a volume final of $0.3 \mathrm{ml}$ (the concentrations of all substances are indicated as final concentrations). The incubation was prolonged for 7.5, 15, $30 \mathrm{~min}$ and it was stopped by adding $3.0 \mathrm{ml}$ chloroform/methanol $(1: 1$, $\mathrm{v} / \mathrm{v}$ ). The organic phase was washed with 0.2 volumes of $0.5 \% \mathrm{NaCl}$. The next day, the upper phase was removed, measured and $0.5 \mathrm{ml}$ were diluted in counting vials with $10 \mathrm{ml}$ Ecoscint A and $1 \mathrm{ml}$ water to evaluate ${ }^{3} \mathrm{H}$-PPC for PC-PLC activity and ${ }^{14} \mathrm{C}-\mathrm{PPC}$ for N-SMase activity. 
The lower phase was used to evaluate the SM-synthase activity. It was dried under nitrogen flow and the lipids were re-suspended with chloroform and separated with thin-layer silica gels (TLC) chromatography by using chloroform/methanol/ammonia $(65: 25: 4$, by vol) as solvent. In the sample, cold SM was added to the tubes before chromatography in order to better identify the spot. The SM was identified on the basis of its migration related to SM standard, localised with iodine vapour and scraped into counting vials with $10 \mathrm{ml}$ Ecoscint $\mathrm{A}$ and $1 \mathrm{ml}$ water. The radioactivity was measured as above reported for the analysis of transcriptional activity of the chromatin. For DAG and ceramide determination, the samples with $1 \mathrm{mg}$ of protein at 0 and $30 \mathrm{~min}$ of incubation were prepared. The content of ceramide was calculated in both control and experimental sample considering the ceramide added to the incubation medium.

Experiment 2. Effect of nuclear membrane or chromatin PC-PLC endogenous activity on $N$ SMase and RSM-synthase - $1 \mathrm{nmol}$ of $\left[{ }^{3} \mathrm{H}\right]-\mathrm{PC}$ was diluted by adding $99 \mathrm{nmol}$ cold PC to a final radioactivity of $1.27 \mathrm{Ci} / \mathrm{mol}$. The preincubation was performed for $60 \mathrm{~min}$ at $37^{\circ} \mathrm{C}$ with a reaction mixture containing $0.1 \mathrm{M}$ Tris $/ \mathrm{HCl} \mathrm{pH} 7.6$ or 8.4 for nuclear membrane or chromatin respectively, $0.3 \mathrm{mM}^{3} \mathrm{H}-\mathrm{PC}, 2 \mathrm{mM} \mathrm{CaCl}_{2}, 0.1 \%$ Triton X-100, sample suspension in $10 \mathrm{mM}$ Tris $+1 \mathrm{mM}$ PMSF (pH 7.6 and $\mathrm{pH} 8.4$ for nuclear membrane and chromatin respectively) equivalent to $200 \mu \mathrm{g}$ protein, to a final volume of $0.2 \mathrm{ml}$. In the control sample, incubation was performed without ${ }^{3} \mathrm{H}-\mathrm{PC}$. At the end of the preincubation, considered 0 , time, $0.3 \mathrm{mM}{ }^{3} \mathrm{H}-\mathrm{PC}+0.3 \mathrm{mM}{ }^{14} \mathrm{C}-\mathrm{SM}, 0.3 \mathrm{mM} \mathrm{DAG}$, and $6 \mathrm{mM} \mathrm{MgCl}_{2}$ were added to a volume final of $0.3 \mathrm{ml}$. (the concentrations of all substances are indicated as final concentrations). The incubation was prolonged for 7.5, 15, $30 \mathrm{~min}$ and it was stopped by adding $3.0 \mathrm{ml}$ chloroform/methanol $(1: 1, \mathrm{v} / \mathrm{v})$. The organic phase was washed with 0.2 volumes of $0.5 \% \mathrm{NaCl}$. The next day, the upper phase was removed, measured and $0.5 \mathrm{ml}$ were diluted in counting vials with $10 \mathrm{ml}$ Ecoscint A and $1 \mathrm{ml}$ water to evaluate ${ }^{3} \mathrm{H}-\mathrm{PPC}$ for PC-PLC and ${ }^{14}$ C-PPC for SMase. The lower phase was used for RSM-synthase evaluation by using the same method of that used for SM-synthase evaluation but utilizing cold PC to identify the spot. The radioactivity was measured and DAG and ceramide content was evaluated as above reported. The content of DAG was calculated in both control and experimental sample considering the DAG added to the incubation medium 
D609 treatment. The nuclear membrane or chromatin corresponding to $200 \mu \mathrm{g}$ protein were incubated with $200 \mathrm{nmol}$ of tricyclodecan-9-yl-xanthogenate (D609) [29] and the N-SMase [25], SM-synthase [27], PC-PLC [29], and RSM-synthase [31] activities were assayed after 0, $7.5,15$ and $30 \mathrm{~min}$.

Statistical analysis - Unless otherwise stated means \pm SD are given. The significance of the differences between the data was checked by student $\tau$ test.

Results

Nuclear Membrane and Chromatin lipid fraction

The results of lipid content and enzyme activities obtained in purified nuclear membrane and chromatin are reported in the Table 1. In the nuclear membrane, the PC content is about 12 times SM content whereas the DAG only 2 times ceramide content. In fact, the $\mathrm{DAG} /$ ceramide ratio is 1.98 . The activities of $\mathrm{N}$-SMase and SM-synthase are similar and their value is $50 \%$ of that of PC-PLC. The activity of RSM-synthase is very low. In the chromatin, the value of PC is 4.47 times higher of SM value. The DAG is 1.57 higher of ceramide. The activity of N-SMase, similar to that of RSM-synthase, is $9 \%$ of the SMsynthase activity. PC-PLC activity value is similar to that of SM-synthase. The results of the lipid composition and enzyme activities in nuclear membrane and chromatin support previous observations [17]. The comparison of the results indicates a strong difference in PC/SM ratio in the two fractions and a very high SMase activity in nuclear membrane whereas the RSMsynthase activity is higher in chromatin.

\section{Characteristics of purified chromatin}

The chromatin isolation procedure used here consists of many treatments that remove first the outer nuclear membrane and then the inner nuclear membrane with a progressive and gentle swelling of the nuclear material that permits a good preservation of the chromatin. The purified chromatin remains transcriptionally active for two hours (Fig.2). Moreover, it is also active after the treatments made for the PC-SM metabolism crosstalk study either after the preincubation time or after incubation time as above reported in the "experiment 1 " and “experiment 2" (Fig.2). 
Effect of endogenous N-SMase on PC-PLC and SM-synthase activities and of endogenous PC-PLC on N-SMase and RSM-synthase activities in nuclear membranes

In nuclear membrane, the values of the lipid metabolism enzyme activities in the control sample are linear in the time. After preincubation ( $0^{\prime}$ time) with ${ }^{14} \mathrm{C}-\mathrm{SM}$ (experiment 1 ) or ${ }^{3} \mathrm{H}-\mathrm{PC}$ (experiment 2), N-SMase activity is $52 \pm 11$ and whereas PC-PLC activity is $97 \pm 15$ $\mathrm{nmol} / \mathrm{mg}$ protein. The preincubation with ${ }^{14} \mathrm{C}-\mathrm{SM}$ does not modify the PC-PLC and SMsynthase activity in the time with respect to the control (Fig. 3a); moreover the preincubation with ${ }^{3} \mathrm{H}-\mathrm{PC}$ does not influence the N-SMase and RSM-synthase activity (Fig. 3b). No variations are observed in DAG and ceramide content at $30 \mathrm{~min}$ of incubation with respect to the control in the experiment 1 (Fig.5a) whereas an increase of DAG is shown in the experiment 2 (Fig.6a)

Effect of endogenous N-SMase on PC-PLC and SM-synthase activities and of endogenous $P C-P L C$ on SMase and RSM-synthase activities in chromatin

In chromatin, the values of the lipid metabolism enzyme activities in the control sample are linear in the time. After preincubation $\left(0^{\prime}\right.$ time) with ${ }^{14} \mathrm{C}-\mathrm{SM}$ (experiment 1$)$ or ${ }^{3} \mathrm{H}-\mathrm{PC}$ (experiment 2), N-SMase activity is $1200 \pm 321$ whereas PC-PLC is $9560 \pm 250 \mathrm{pmol} / \mathrm{mg}$ protein. The preincubation with ${ }^{14} \mathrm{C}$-SM produces a PC-PLC activity increase of 1.63, 6.64 and 5.56 times after 7.5, 15 and 30 min respectively in comparison with the control (Fig.4a). At the same times the SM-synthase activity increases of 2.06, 1.99 and 10.94 times (Fig.4a). After 30 min the DAG content increases of 3.81 and ceramide content decreases 4.19 times with respect to the control (Fig.5b). DAG/ceramide ratio is 1.5 and 3.0 after 0 and $30 \mathrm{~min}$ respectively in the control whereas the values are 0.93 and 40.03 in the experimental sample. Therefore endogenous $\mathrm{N}$-SMase activity induces an enrichment of ceramide pool that is responsible for first PC-PLC and after SM-synthase activation enriching the DAG pool and reducing that of ceramide in the chromatin.

The endogenous PC-PLC activity produces a N-SMase activity increase of 1.75, 1.5 and 1.62 times after 7.5, 15 and 30 min respectively compared to the control (Fig.4b). RSM-synthase activity has the same value at $7.5 \mathrm{~min}$ and increases 3.2 times at $15 \mathrm{~min}$ and 2.90 times at 30 min with respect to the control (Fig.4b). Therefore PC-PLC stimulates first N-SMase and then RSM-synthase activity. After $30 \mathrm{~min}$ the DAG content decreases 1.76 times and that of ceramide increases 2.90 times with respect to the control. DAG/ceramide ratio is 1.64 and 3.01 after 0 and $30 \mathrm{~min}$ in the control whereas in the experimental sample the values are 4.36 
and 0.59 respectively (Fig.6b). Therefore in the chromatin PC-PLC activity determines an enrichment of DAG pool that is responsible for first N-SMase and after RSM-synthase activation enriching the ceramide pool and reducing that of DAG.

\section{Effect of D609 on enzyme activities}

To better verify the interaction between PC and SM metabolism, incubation of nuclear membrane and chromatin by D609 was performed. The results show that in nuclear membrane the PC-PLC (Fig.7a) and SM-synthase (Fig.7b) activity is inhibited 99\% and 35\% respectively after $30 \mathrm{~min}$ in comparison with the control. No modifications are observed for N-SMase (Fig.7c) and RSM-synthase (Fig.7d).

In chromatin, D609 treatment induces a PC-PLC activity reduction of $22 \%, 48 \%$ and $40 \%$ after 7.5, 15 and $30 \mathrm{~min}$ respectively (Fig. 8a). At the same times an inhibition equal to 59\%, $75 \%$ and $86 \%$ for SM-synthase (Fig. 8 b), 1.7\%, 10\% and $48 \%$ for N-SMase (Fig.8c) and 14\%, $13 \%$ and $45 \%$ for RSM-synthase (Fig.8d) appears. Therefore D609 acts first on SM-synthase and then on PC-PLC; the reduction of DAG pool could be responsible for N-SMase and RSM-synthase activity inhibition.

\section{Phosphatidylcholine-sphingomyelin metabolism during rat liver regeneration}

In order to study if the crosstalk of chromatin PC and SM metabolism obtained in vitro could occur in vivo, the activity of PC-PLC, N-SMase, SM-synthase and RSM-synthase has been evaluated in the regenerating rat liver after partial hepatectomy. The results show that in the nuclear membrane PC-PLC and N-SMase activity increases progressively in time until 24 hours, the SM-synthase forms a peak at 18 hours whereas RSM-synthase does not show any variation (Fig. 9a). In chromatin the activity of PC-PLC increases at 12 hours and it is reduced at 18 hours when N-SMase and RSM-synthase activity increases, whereas the SMsynthase activity increases strongly at 24 hours together to a new increase of PC-PLC activity (Fig.9b). No significant modifications are reported for sham operated animals.

\section{Discussion}

The results highlighted clearly that in nuclear membrane the metabolism of PC is independent from that of SM and vice-versa, whereas in chromatin a crosstalk between the two lipid metabolisms exists. To study these metabolic interactions, each enzyme has been activated by adding the substrate of the reaction since until now do not exist physiologic activators or 
inducers. Watanabe et al. have shown that Fas activates the N-SMase and inhibits SMsynthase in the nuclei isolated from human leukaemia Jurkat T-lymphoid leukaemia cells [21]. The authors have studied the whole nuclei whereas our results are referred to the nuclear membrane and chromatin purified from isolated nuclei which have different physico-chemical properties $[25,27,29,31]$. In chromatin the mechanism of the enzyme regulation was very fine. In fact the N-SMase activity reduces the SM level with consequent enrichment of ceramide pool that is responsible for the stimulation of PC utilization first by PC-PLC and then by SM-synthase activation. The PC-PLC activity degrades PC freeing PPC and DAG; the SM-synthase activity permits to re-synthesise SM by using ceramide free and PC as source of PPC with consequent release of DAG. In this way an early and a later production of DAG with a reduction of ceramide pool occur with consequent increase of DAG/ceramide ratio. Differently the PC-PLC activity determines an enrichment of DAG pool that is responsible for first N-SMase and then RSM-synthase activation. N-SMase degrades SM freeing PPC and ceramide whereas RSM-synthase re-synthesises PC by using DAG free and PPC derived from SM with release of ceramide. Consequently, as above reported for the DAG, an early and a later ceramide production are obtained. Therefore in the chromatin the SM and PC metabolisms are very correlated. The results are supported by the experiment with D609, a drug known to be an inhibitor of PC-PLC [44] and SM-synthase [45] also at nuclear level [27]. This effect is evident in nuclear membrane in which the drug acts at the same time on the two enzymes even if with different percentage. No inhibitor effect on the N-SMase or RSM-synthase activity is shown. In chromatin the D609 inhibitor effect on different enzymes is evident at various times. In fact, it has been demonstrated first an inhibition of SM-synthase and then of PC-PLC activity; the last is responsible for a later N-SMase and RSM-synthase inhibition. Therefore a mechanism of internal regulation of lipid metabolism exists in chromatin probably to maintain an equilibrium either between SM and PC or ceramide and DAG when the cells are in the physiological state. To study the possible role of chromatin SM-PC crosstalk in vivo, it has been stimulated liver cell proliferation by partial hepatectomy. In fact, liver regeneration represents a good model of synchronous proliferation in vivo. The hepatocytes enter in G1 phase and begin to synthesise DNA 18 hrs after hepatectomy and divide after $24 \mathrm{hrs}$. Our results show that during liver regeneration the metabolisms of PC and SM localised in nuclear membrane do not are in relation whereas those present in chromatin present a fine regulation mechanism. In fact, the activity of chromatin PC-PLC increases at the beginning of the S-phase and is reduced during S-phase 
when N-SMase and RSM-synthase activities increase whereas the SM-synthase increases strongly only at the end of the S-phase. At the moment we do not have sufficient data to describe the exact mechanism of action for ceramide derived from N-SMase on PC-PLC and for DAG derived from PC-PLC on N-SMase. It is possible to suppose the involvement of different DAG [44] or ceramide [45] dependent PKC isoforms. It has been demonstrated that PKC alpha is stimulated by DAG [46] and inhibited by ceramide [45]. In HL-60 cells, the depletion of PKC alpha from the cytosol abolishes the stimulation vitamin D3-dependent of N-SMase, enzyme inhibited by PKC delta [47]. In fact the PKC delta depletion with specific antibodies increases significantly the SMase activity [47]. On the other hand the PKC delta is a ceramide activated kinases [48]. It is possible that DAG stimulates SM hydrolysis [49] by activating PKC alpha or inhibiting PKC delta. Inside the nuclei isolated from rat liver the PLC activity increases PKC alpha [50] whereas in the nuclei isolated from BL6 murine melanoma cells, that do not express the PKC $\delta$ [51], the overexpression of this PKC isoform inhibits the N-SMase activity and stimulates the SM-synthase [41]. Therefore it is possible to hypothesise that at the nuclear level the ceramide could have inhibitor effect on DAG activated kinases, such as PKC alpha which, for regulatory mechanism, could stimulate PCPLC increasing the DAG pool. Vice-versa, the DAG could have inhibitor effect on ceramide activated kinases, such as delta isoform with consequent stimulation of N-SMase increasing the ceramide pool. Probably D609 by inhibiting SM-synthase and PC-PLC activity and consequently reducing the level of DAG, does not permit the inhibition of the PKC delta and therefore the N-SMase activity results inhibited.

In conclusion our results show that SM and PC can be synthesised and hydrolysed directly in chromatin with a regulatory mechanism, suggesting that they could have a specific role in relation to cell function.

\section{Acknowledgements}

Support of this work by Ministero dell' Università e Ricerca, Agenzia Spaziale Italiana (ASI), and Fondazione Cassa di Risparmio di Perugia is gratefully acknowledged. We thank Bartoccini E., Bernardini I., Cascianelli G., Marini F. for the technical assistance 


\section{References}

1. Levade, T., and Jaffrezou, J. P. (1999) Signalling sphingomyelinases: which, where, how and why? Biochim. Biophys. Acta 1438, 1-17.

2. Wright, M.M, Howe, A.G., Zaremberg, V. (2004) Cell membranes and apoptosis: role of cardiolipin, phosphatidylcholine, and anticancer lipid analogues. Biochem. Cell Biol. 82, 18-26

3. Lang, D., Leray, C., Mestre, R., Massarelli, R., Dreyfus, H., Freysz, L. (1995) Molecular species analysis of 1,2-diglycerides on phorbol ester stimulation of LA-N-1 neuroblastoma cells during proliferation and differentiation. J. Neurochem. 65, 810817

4. Hannun, Y.A. and Obeid, L.M. (2002) The Ceramide-centric universe of lipidmediated cell regulation: stress encounters of the lipid kind. J. Biol. Chem. 277, 25847-25850

5. Luberto, C., Kraveka, J.M. and Hannun, Y.A. (2002) Ceramide regulation of apoptosis versus differentiation: a walk on a fine line. Lessons from neurobiology. Neurochem. Res. 27, 609-617

6. Spence, M.W. (1993) Sphingomyelinases. Adv. Lipid Res. 26, 3-23

7. Marggraf, W.D. and Kanfer, J.N. (1984) The phosphorylcholine acceptor in the phosphatidylcholine:ceramide cholinephosphotransferase reaction. Is the enzyme a transferase or a hydrolase? Biochim.Biophys.Acta 793, 346-353

8. Exton, J.H. (1994) Phosphatidylcholine breakdown and signal transduction. Biochim. Biophys. Acta 1212, 26-42

9. Allan, D. and Quinn, P. (1988) Resynthesis of sphingomyelin from plasma-membrane phosphatidylcholine in BHK cells treated with Staphylococcus aureus sphingomyelinase. Biochem. J. 254, 765-771

10. van Dijk, M., Muriana, F.J., van Der Hoeven, P.C., de Widt, J., Schaap, D., Moolenaar, W.H., van Blitterswijk, W.J. (1997) Diacylglycerol generated by exogenous phospholipase $\mathrm{C}$ activates the mitogen-activated protein kinase pathway independent of Ras- and phorbol ester-sensitive protein kinase $\mathrm{C}$ : dependence on protein kinase C-zeta. Biochem J. 323, 693-369

11. Cross, T.G., Scheel-Toellner, D., Henriquez, N.V., Deacon, E., Salmon, M., Lord, J,M. (2000) Serine/threonine protein kinases and apoptosis. Exp. Cell Res. 256, 34-41 
12. Kolesnick, R.N., Clegg, S. (1988) 1,2-Diacylglycerols, but not phorbol esters, activate a potential inhibitory pathway for protein kinase $\mathrm{C}$ in $\mathrm{GH} 3$ pituitary cells. Evidence for involvement of a sphingomyelinase. J Biol Chem. 263, 6534-6537

13. Hampton, R.Y., and Morand, O.H. (1989) Sphingomyelin synthase and PKC activation. Science 246, 1050.

14. Schutze, S., Potthoff, K., Machleidt, T., Berivic, D., Wiegmann, K., and Kronke, M. (1992) TNF activates NF-kappa B by phosphatidylcholine-specific phospholipase Cinduced "acidic" sphingomyelin breakdown. Cell 71, 765-776

15. Maupas-Schwalm, F., Auge, N., Robinet, C., Cambus, J.P., Parsons, S.J., Salvayre, R., Negre-Salvayre, A. (2004) The sphingomyelin/ceramide pathway is involved in ERK1/2 phosphorylation, cell proliferation, and uPAR overexpression induced by tissue-type plasminogen activator. FASEB J. 18, 1398-1400.

16. Van der Luit, A.H., Budde, M., Zerp, S., Caan, W., Klarenbeek, J.B., Verheij, M., Van Blitterswijk, W.J. (2007) Resistance to alkyl-lysophospholipid-induced apoptosis due to downregulated sphingomyelin synthase 1 expression with consequent sphingomyelin- and cholesterol-deficiency in lipid rafts. Biochem. J. 401, 541-549

17. Albi, E. and Viola Magni, M.P. (2004) The role of intranuclear lipids. Biol. Cell 96, 657-667

18. Ledeen, R.W. and $\mathrm{Wu}, \mathrm{G}$. (2004) Nuclear lipids: key signalling effectors in the nervous system and other tissues. J. Lipid Res. 45, 1-8

19. Ledeen, R.W. and $\mathrm{Wu}, \mathrm{G}$. (2006) Sphingolipids of the nucleus and their role in nuclear signaling. Biochim. Biophys. Acta. 1761, 588-598

20. Martelli, A.M., Fala, F., Faenza, I., Billi, A.M., Cappellini, A., Manzoli, L., Cocco, L. (2004) Metabolism and signaling activities of nuclear lipids. Cell Mol. Life Sci. 61, 1143-1156

21. Watanabe, M., Kitano, T., Kondo, T., Yabu, T., Taguchi, Y., Tashima, M., Umehara, H., Domae, N., Uchiyama, T., Okazaki, T. (2004) Increase of nuclear ceramide through caspase-3-dependent regulation of the "sphingomyelin cycle" in Fas-induced apoptosis. Cancer Res. 64, 1000-1007

22. Tamiya-Koizumi, K., Umekawa, H., Yoshida, S., Kojima, K. (1989) Existence of $\mathrm{Mg} 2+$-dependent, neutral sphingomyelinase in nuclei of rat ascites hepatoma cells. J. Biochem. 106, 593-598 
23. Neitcheva, T., Peeva, D. (1995) Phospholipid composition, phospholipase A2 and sphingomyelinase activities in rat liver nuclear membrane and matrix. Int $\mathrm{J}$ Biochem Cell Biol. 27, 995-1001

24. Romanenko, E.B., Demidenko, Z.N., Vanyushin, B.F. (1998) RNA-polymerase, DNA-polymerase, DNA-methyltransferase and sphingomyelinase activities in liver nuclei of rats of different Age. Biochemistry 63, 159-163

25. Albi, E. and Viola Magni, M.P. (1997) Chromatin neutral spingomyelinase and its role in hepatic regeneration. Biochim. Biophys. Res. Commun. 236, 29-33

26. Mizutani, Y., Tamiya-Koizumi, K., Nakamura, N., Kobayashi, M., Hirabayashi, Y., Yoshida, S. (2001) Nuclear localization of neutral sphingomyelinase 1: biochemical and immunocytochemical analyses. J Cell Sci. 114, 3727-3736

27. Albi, E., Viola Magni, M.P. (1999) Sphingomyelin-Synthase in Rat Liver Nuclear Membrane and Chromatin. FEBS Letters 460,369-372

28. Kavok, N.S., Krasilnikova, O.A., Babenko, N.A. (2003) Increase in diacylglycerol production by liver and liver cell nuclei at old age. Exp. Gerontol. 38, 441-447

29. Albi, E. and Viola Magni, M.P. (1999) Phosphatidylcholine-Dependent Phospholipase C in Rat Liver Chromatin. Biochem. Biophys. Res. Commun. 265, 640-643

30. Ramoni, C., Spadaro, F., Barletta, B., Dupuis, M.L., Podo, F. (2004) Phosphatidylcholine-specific phospholipase $\mathrm{C}$ in mitogen-stimulated fibroblasts. Exp Cell Res. 299, 370-382

31. Albi, E., Lazzarini, R., Viola Magni, M. (2003) Reverse Sphingomyelin-Synthase in Rat Liver Chromatin. FEBS Letters 549, 152-156

32. Alessenko, A. and Chatterjee. S. (1995) Neutral sphingomyelinase: localization in rat liver nuclei and involvement in regeneration/proliferation. Mol. Cell Biochem. 143, 169-174

33. Tsugane, K., Tamiya-Koizumi, K., Nagino, M., Nimura, Y., Yoshida, S. (1999) A possible role of nuclear ceramide and sphingosine in hepatocyte apoptosis in rat liver. J. Hepatol. 31, 8-17

34. Rossi, G., Viola Magni, M., Albi, E. (2007) Signal transducer and activator of transcription 3 and sphingomyelin metabolism in intranuclear complex during cell proliferation. Arch. Biochem. Biophys. in press 
35. Albi, E., Peloso, I., Viola Magni, M.P. (1999) Nuclear Membrane SphingomyelinCholesterol Changes in Rat Liver after Hepatectomy. Biochem. Biophys. Res. Commun. 262, 692-695

36. Tomassoni, M.L., Albi, E., Viola Magni, M.P. (1999) Changes of nuclear membrane fluidity during rat liver regeneration. Biochem. Mol. Biol. Intern. (IUBMB LIFE) 47, 1049-1059

37. Tomassoni, M.L., Amori, D., Magni, M.V. (1999) Changes of nuclear membrane lipid composition affect RNA nucleocytoplasmic transport. Biochem. Biophys. Res. Commun. 258, 476-481

38. Albi, E., Pieroni, S., Viola Magni, M.P., Sartori, C (2003) Chromatin sphingomyelin changes in cell proliferation and/or apoptosis induced by ciprofibrate. J. Cell Physiol. 196, 354-361

39. Albi, E., Rossi, G., Maraldi, N.M., Viola Magni, M.P., Castaldi, S., Solimando, L., Zini, N. (2003). Involvement of nuclear Phosphatidylinositol-dependent Phospholipases C in cell cycle progression during rat liver. J. Cell Physiol. 197, 181188

40. Gould, H.J., Maryanka, D., Fey, S.J., Cowling, G.J., Allan, J. (1978) The assay of globin gene transcription in reconstituted chromatin. Methods Cell Biol. 19:387-422

41. Schneider, W. C. (1957). Determination of nucleic acids by pentose analysis. Methods Enzymol. 3, 680-684

42. Previati, M., Bertolaso,L., Tramarin,M., Bertagnolo,V., and Capitani,S. (1996) Low nanogram range quantitation of diglycerides and ceramide by high-performance liquid chromatography Anal Biochem 233, 108-114.

43. Rastegar,A, Pelletier,A., Duportail,G., Freysz,L., and Leray,C. (1990) Sensitive analysis of phospholipid molecular species by high-performance liquid chromatography using fluorescent naproxen derivatives of diacylglycerols. $J$. Chromatogr. 518, 157-165

44. Li, F., Wu, N., Su, R.B., Zheng, J.Q., Xu, B., Lu, X.Q., Cong, B., Li, J. (2006) Involvement of phosphatidylcholine-selective phospholipase $\mathrm{C}$ in activation of mitogen-activated protein kinase pathways in imidazoline receptor antisera-selected protein. J. Cell Biochem. 98, 1615-1628 
45. Meng, A., Luberto, C., Meier, P., Bai, A., Yang, X., Hannun, Y.A., Zhou, D. (2004) Sphingomyelin synthase as a potential target for D609-induced apoptosis in U937 human monocytic leukemia cells. Exp. Cell Res. 292, 385-392

46. Albi, E., La Porta, C.A.M., Cataldi, S., Viola Magni, M.P. (2005) Nuclear sphingomyelin-synthase and protein kinase $\mathrm{C}$ delta in melanoma cells. Arch. Biochem. Biophys. 438, 156-161

47. Stahelin, R.V., Digman, M.A., Medkova, M., Ananthanarayanan, B., Rafter, J.D., Melowic, H.R., Cho, W. (2004) Mechanism of diacylglycerol-induced membrane targeting and activation of protein kinase Cdelta. J. Biol. Chem. 279, 29501-29512.

48. Abboushi, N., El-Hed, A., El-Assaad, W., Kozhaya, L., El-Sabban, M.E., Bazarbachi, A., Badreddine, R., Bielawska, A., Usta, J., Dbaibo, G.S. (2004) Ceramide inhibits IL2 production by preventing protein kinase C-dependent NF-kappaB activation: possible role in protein kinase Ctheta regulation. J. Immunol. 173, 3193-3200

49. Shen, Y.M., Chertihin, O.I., Biltonen, R. L., Sando, J.J. (1999) Lipid-dependent activation of protein kinase C-alpha by normal alcohols. J. Biol. Chem. 274, 3403634044

50. Visnjic, D., Batinic, D., Banfic, H. (1999) Different roles of protein kinase C alpha and delta isoforms in the regulation of neutral sphingomyelinase activity in HL-60 cells. Biochem. J. 344, 921-928

51. Gopee, N.V., Sharma, R.P. (2003) Sphingolipid bases and their phosphatases: transient activation and delayed repression of protein kinase $\mathrm{C}$ isoforms and their possible involvement in fumonisin B1 cytotoxicity. Toxicology. 187, 239-250

52. Kolesnick, R.N. (1987) 1,2-Diacylglycerols but not phorbol esters stimulate sphingomyelin hydrolysis in GH3 pituitary cells. J. Biol. Chem. 262, 16759-16762

53. Akutagawa, A., Fukami, K., Banno, Y., Takenawa, T., Kannagi, R., Yokoyama, Y., Oda, K., Nagino, M., Nimura, Y., Yoshida, S., Tamiya-Koizumi, K. (2006) Disruption of phospholipase Cdelta4 gene modulates the liver regeneration in cooperation with nuclear protein kinase C. J. Biochem. (Tokyo) 140, 619-625

54. La Porta, C.A.M., Di Dio, A., Porro, D., Comolli, R. (2000) Overexpression of novel protein kinase $\mathrm{C}$ delta in BL6 murine melanoma cells inhibits the proliferative capacity in vitro but enhances the metastatic potential in vivo. Melanoma Res. 10, 93102 
Figure legends

Fig.1

Experimental plan. In the "experiment 1" the preincubation with ${ }^{14} \mathrm{C}-\mathrm{SM}$ induces activation of $\mathrm{N}$-SMase. In the control sample the preincubation was performed without ${ }^{14} \mathrm{C}-\mathrm{SM}$. The effects of N-SMase activity in the presence of specific substrate on PC-PLC and SM-synthase activity were evaluated at different times of incubation as reported in the "Materials and Methods" section. In the "experiment 2 " the preincubation with ${ }^{3} \mathrm{H}-\mathrm{PC}$ induces activation of PC-PLC. In the control sample the preincubation was performed without ${ }^{3} \mathrm{H}-\mathrm{PC}$. The effects of PC-PLC activity in the presence of specific substrate on N-SMase and RSM-synthase activity were evaluated at different time of incubation as reported in the "Materials and Methods" section.

Fig. 2

Chromatin transcription. Incubation was performed as reported in the "Materials and Methods" section. The values are expressed as cpm/mg RNA and the values represent the mean \pm S.D. of four separated experiments performed in duplicate. ${ }^{* *} \mathrm{P}<0.01$ versus 0 time. Control = chromatin incubated without $\mathrm{SM}$ or $\mathrm{PC}$; $\mathrm{SM}=$ chromatin incubated with $0.1 \mathrm{mM}$ $\mathrm{SM}$; $\mathrm{PC}=$ chromatin incubated with $0.3 \mathrm{mM}$ PC; Exp. $1=$ experiment 1 and Exp. 2= experiment 2 are reported in the "Materials and Methods" section.

Fig. 3

Sphingomyelin and Phosphatidylcholine metabolism enzymes in nuclear membrane at different incubation times: a) experiment 1 : effect of endogenous sphingomyelinase activity in the presence of specific substrate; b) experiment 2: effect of endogenous phosphatidylcholine-dependent phospholipase $\mathrm{C}$ activity in the presence of specific substrate. The enzyme activities are expressed as $\mathrm{nmol} / \mathrm{mg}$ protein and the values represent the mean \pm S.D. of five separated experiments performed in duplicate. In (b) the right ordinate is referred to RSM-synthase activity ( $\mathrm{pmol} / \mathrm{mg}$ protein). PC-PLC: phosphatidylcholine-dependent 
phospholipase C; SM-synthase, sphingomyelin-synthase; N-SMase, neutralsphingomyelinase; RSM-synthase, reverse sphingomyelin-synthase

Fig. 4

Sphingomyelin and Phosphatidylcholine metabolism enzymes in chromatin at different incubation times: a) experiment 1: effect of endogenous sphingomyelinase activity in the presence of specific substrate; b) experiment 2: effect of endogenous phosphatidylcholinedependent phospholipase $\mathrm{C}$ activity in the presence of specific substrate. The enzyme activities are expressed as $\mathrm{pmol} / \mathrm{mg}$ protein and the values represent the mean \pm S.D. of five separated experiments performed in duplicate. $* *$ P $<0.01$ versus control. PC-PLC: phosphatidylcholine-dependent phospholipase C; SM-synthase, sphingomyelin-synthase; NSMase, neutral-sphingomyelinase; RSM-synthase, reverse sphingomyelin-synthase

Fig. 5

Diacylglycerol and ceramide content in a) nuclear membrane and b) chromatin after endogenous sphingomyelinase activity in the presence of specific substrate.

The data represent the values obtained after $30 \mathrm{~min}$ of incubation and were calculated taking into account the ceramide added. The values were expressed as nmol/mg protein and represent the mean \pm S.D. of five separated experiments performed in duplicate. Significance ** $\mathrm{P}<0.01$ versus control. DAG, diacylglycerol.

Fig. 6

Diacylglycerol and ceramide content in a) nuclear membrane and b) chromatin after endogenous phosphatidylcholine-specific phospholipase $\mathrm{C}$ activity in the presence of specific substrate.

The data represent the values obtained after $30 \mathrm{~min}$ of incubation and were calculated taking in account the diacylglycerol added. The values were expressed as nmol/mg protein and represent the mean \pm S.D. of five separated experiments performed in duplicate. Significance ** $\mathrm{P}<0.01$ versus control. DAG, diacylglycerol.

Fig. 7 
Effect of the D609 treatment on lipid enzymatic activities present in Nuclear Membrane. a) PC-PLC, phosphatidylcholine-dependent phospholipase C; b) SM-synthase, sphingomyelin-synthase; c) N-SMase, neutral-sphingomyelinase; d) RSM-synthase, reverse sphingomyelin-synthase. $\mathrm{C}=$ control sample incubated without $\mathrm{D} 609 ; \mathrm{Ex}=$ experimental sample incubated in the presence of D609. The enzyme activities were expressed as nmol/mg protein and the values represent the mean \pm S.D. of four separated experiments performed in duplicate. Significance $* * \mathrm{P}<0.01$ versus control.

Fig. 8

Effect of the D609 treatment on lipid enzymatic activities present in Chromatin.

a) PC-PLC, phosphatidylcholine-dependent phospholipase C; b) SM-synthase, sphingomyelin-synthase; c) N-SMase, neutral-sphingomyelinase; d) RSM-synthase, reverse sphingomyelin-synthase. $\mathrm{C}=$ control sample incubated without $\mathrm{D} 609 ; \mathrm{Ex}=$ experimental sample incubated in the presence of D609. The enzyme activities were expressed as pmol $/ \mathrm{mg}$ protein and the values represent the mean \pm S.D. of four separated experiments performed in duplicate. Significance $* * \mathrm{P}<0.01$ versus control.

Fig.9

Behaviour of lipid enzyme activities during rat liver regeneration. Cell proliferation is induced by partial hepatectomy as reported in the "Materials and Methods"; a) nuclear membrane and b) chromatin were prepared at different times after operation. The enzyme activities were expressed as $\mathrm{pmol} / \mathrm{mg}$ protein $/ \mathrm{min}$ and the values represent the mean \pm S.D. of four separated experiments performed in duplicate. In (a) the right ordinate is referred to PC-PLC activity. Significance $* * \mathrm{P}<0.01$ versus 0 time. PC-PLC: phosphatidylcholinedependent phospholipase C; SM-synthase, sphingomyelin-synthase; N-SMase, neutralsphingomyelinase; RSM-synthase, reverse sphingomyelin-synthase 
Tab.1

\begin{tabular}{|c|c|c|}
\hline & Nuclear Membrane & Chrộmatin \\
\hline SM & $5.04 \pm 0.63$ & 1.05 空 $0.48 * *$ \\
\hline PC & $61.07 \pm 7.33$ & 4.69 要 $0.49 * *$ \\
\hline Ceramide & $1.11 \pm 0.72$ & $1.96 \underline{\mathscr{g}} 0.31$ \\
\hline DAG & $2.20 \pm 0.45$ & $3.07 \frac{\Xi}{\varrho} 0.25$ \\
\hline N-SMase & $899.05 \pm 17.58$ & 25.0 站 $0.32 * *$ \\
\hline SM-synthase & $768.43 \pm 30.12$ & $265.04 \underset{\frac{1}{4}}{\stackrel{1}{4}} 23.11$ \\
\hline PC-PLC & $1640 \pm 77.04$ & $215.99 \underset{\mathrm{I}}{\mathrm{I}} \mathrm{F}$ \\
\hline RSM-synthase & $1.05 \pm 0.20$ & $\begin{array}{c}34.850+1 \\
\sum \\
\underline{\infty}\end{array}$ \\
\hline
\end{tabular}

Lipid content and enzyme lipid metabolism activities in Nuclear Membrane and Chromatin. The data represent the mean $\pm \mathrm{SD}$ of six separated experiments and are expressed as nmol/mg protein for sphingomyelin (SM), phosphatidylcholine (PC), ceramide and diacylglycerol (DAG) and pmol/mg protein/min for enzymatic activities. Significance $* * \mathrm{P}<0.01$ versus nuclear membrane. 


\section{Fig.1}

Experiment 1

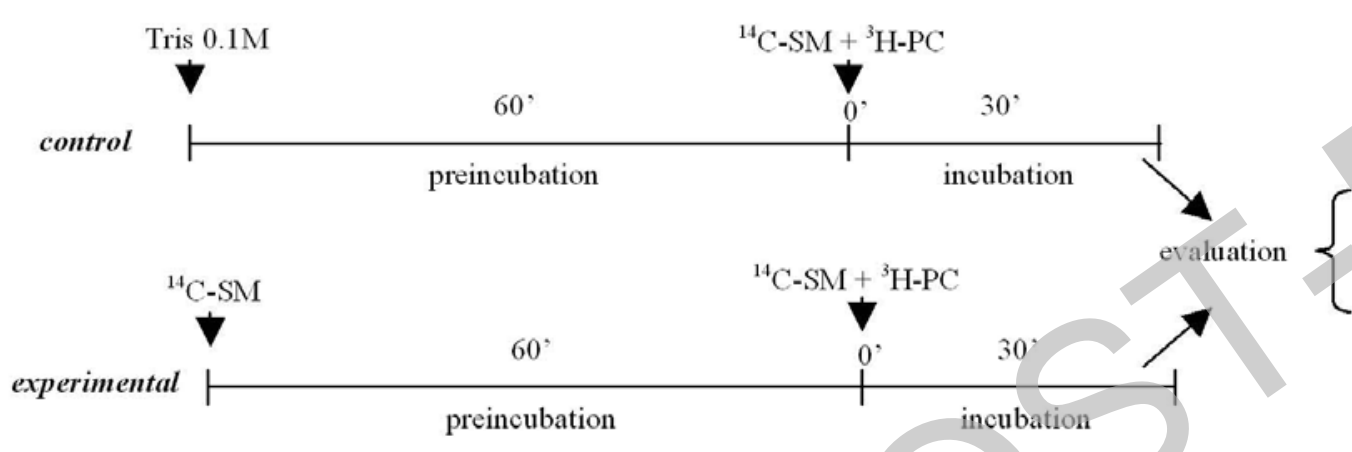

ZPC-PLC

Of-synthase

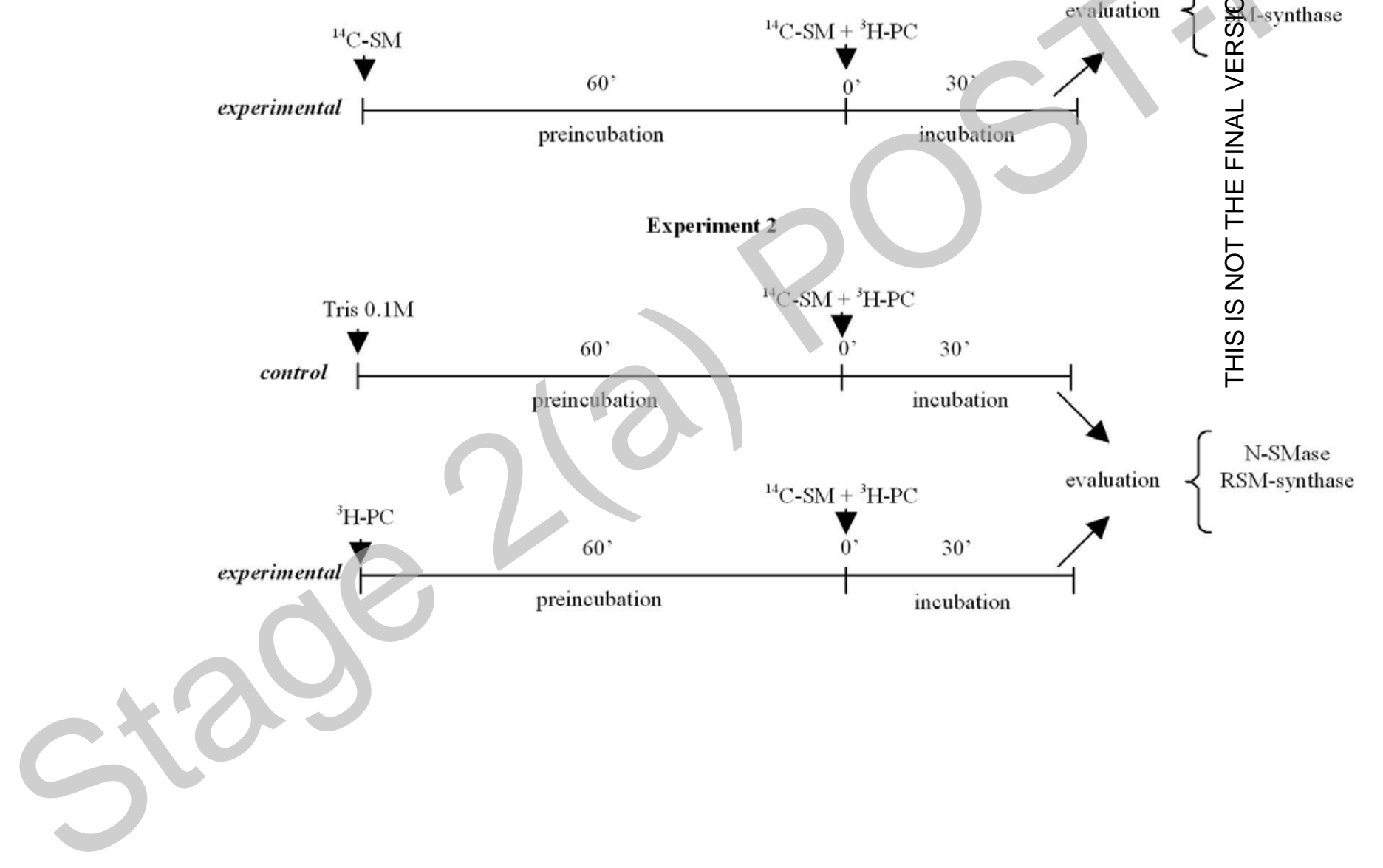

Licenced copy. Copying is not permitted, except with prior permission and as allowed by law. (c) 2007 The Authors Journal compilation (@ 2007 Biochemical Society 
Fig. 2

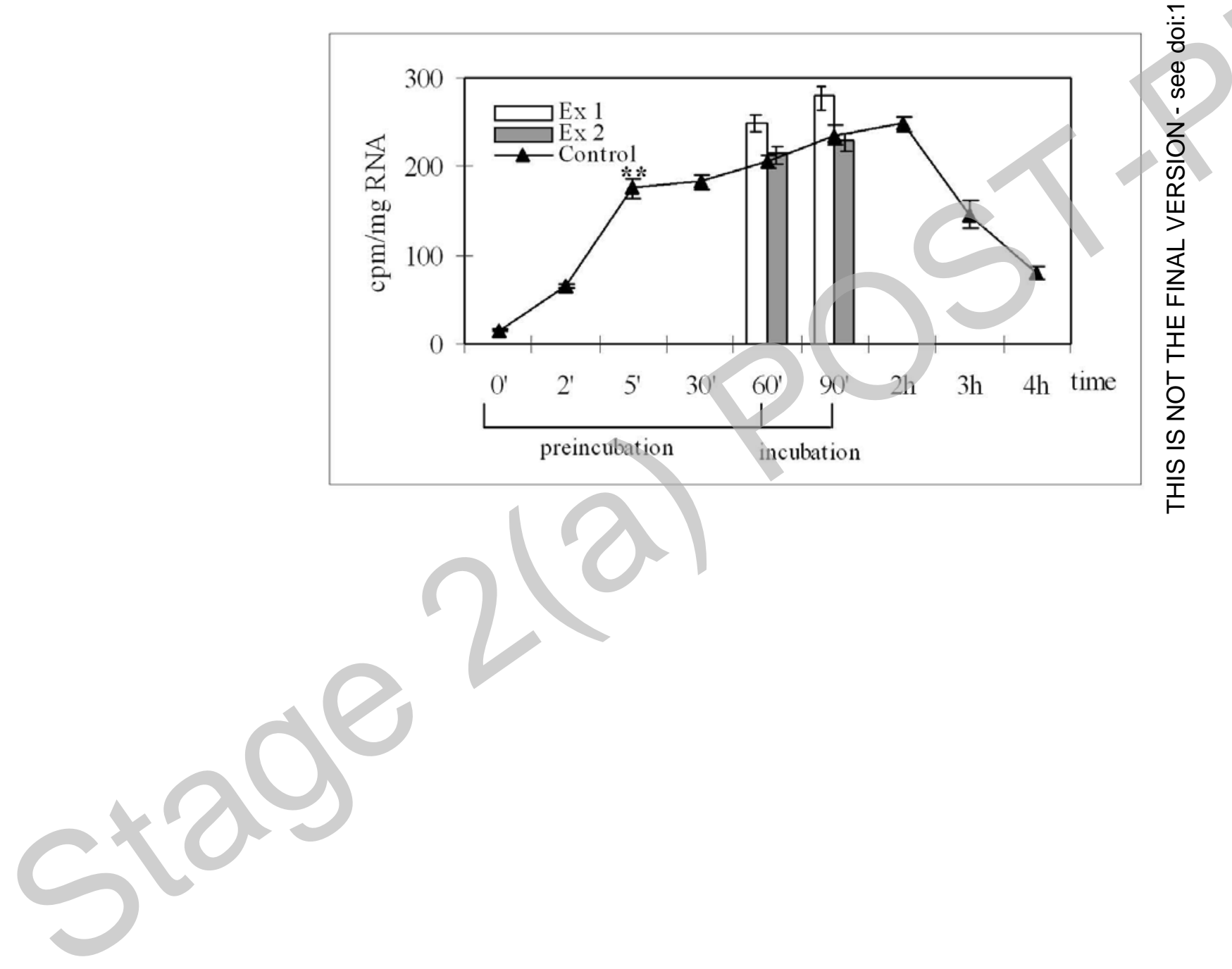

Licenced copy. Copying is not permitted, except with prior permission and as allowed by law. (C) 2007 The Authors Journal compilation (c) 2007 Biochemical Society 


\section{Fig.3}

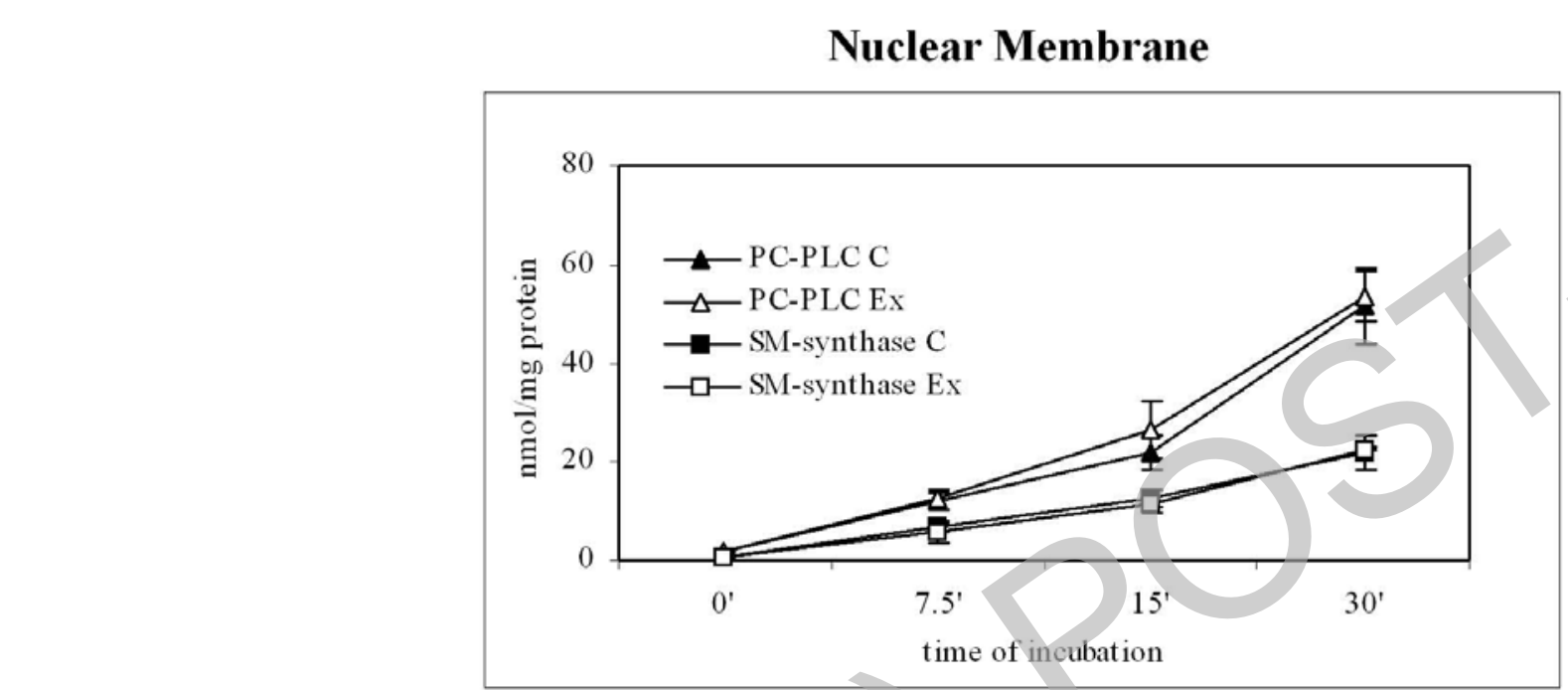

a)

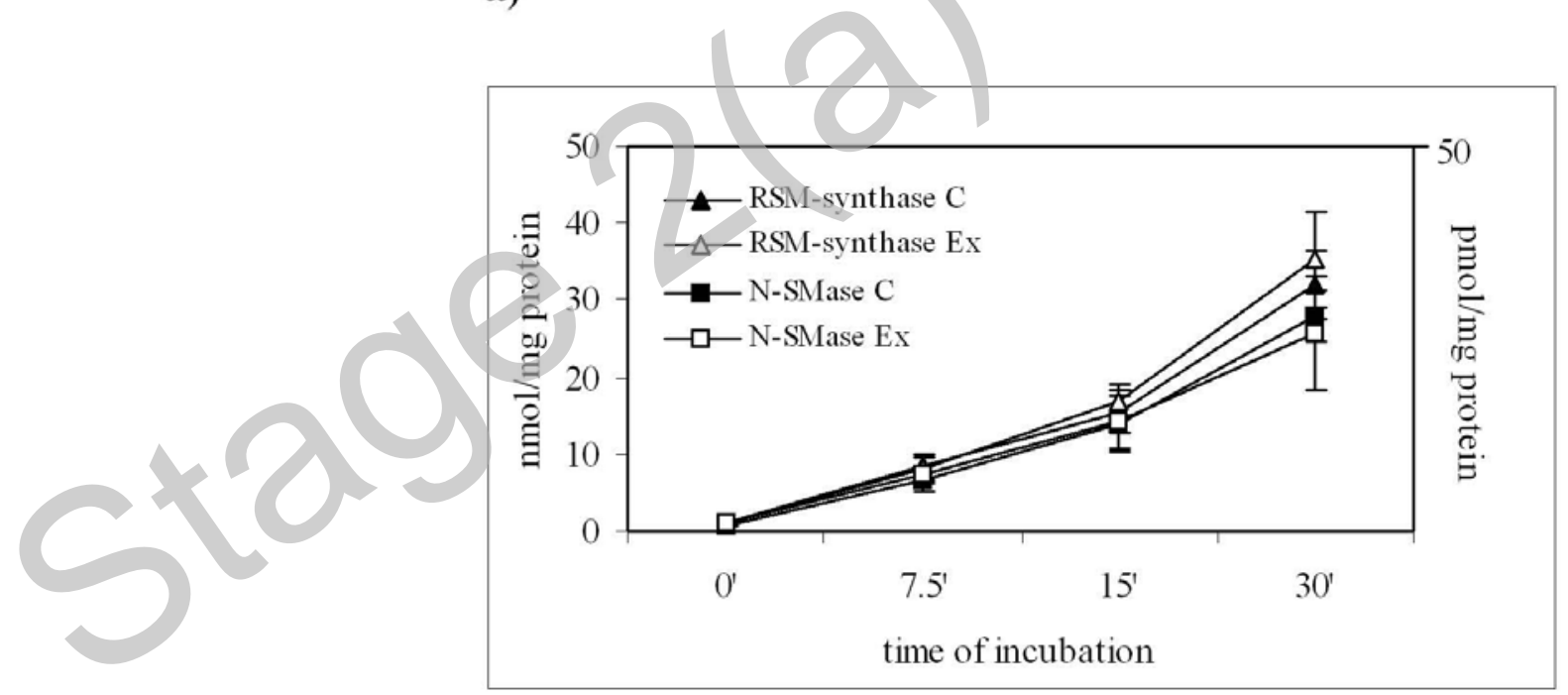

b)

Licenced copy. Copying is not permitted, except with prior permission and as allowed by law. (c) 2007 The Authors Journal compilation (c) 2007 Biochemical Society 
Fig.4

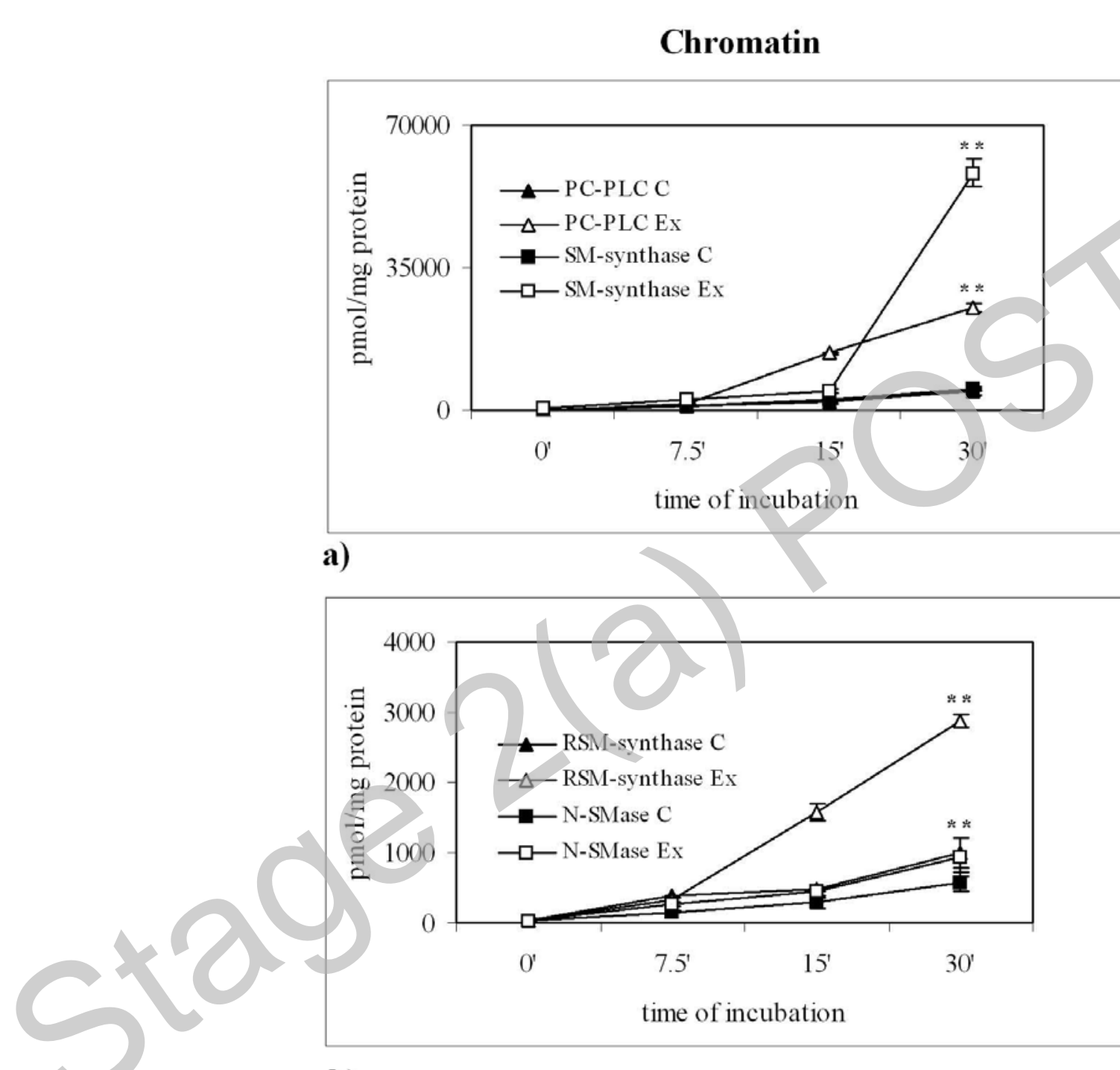

b)

Licenced copy. Copying is not permitted, except with prior permission and as allowed by law. (c) 2007 The Authors Journal compilation (@ 2007 Biochemical Society 
Fig.5

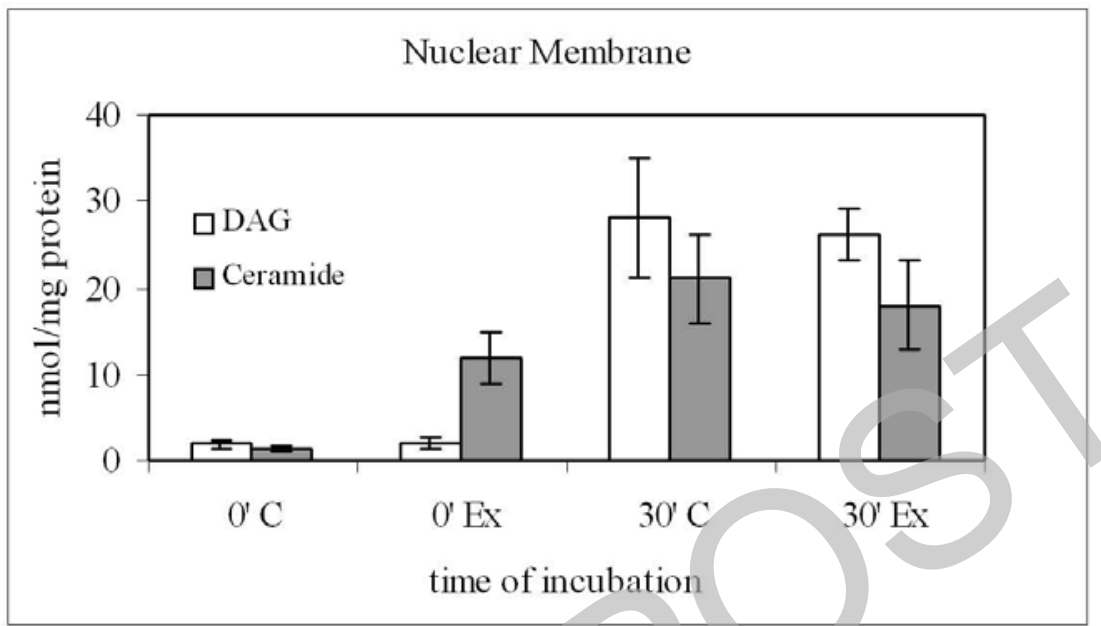

a)

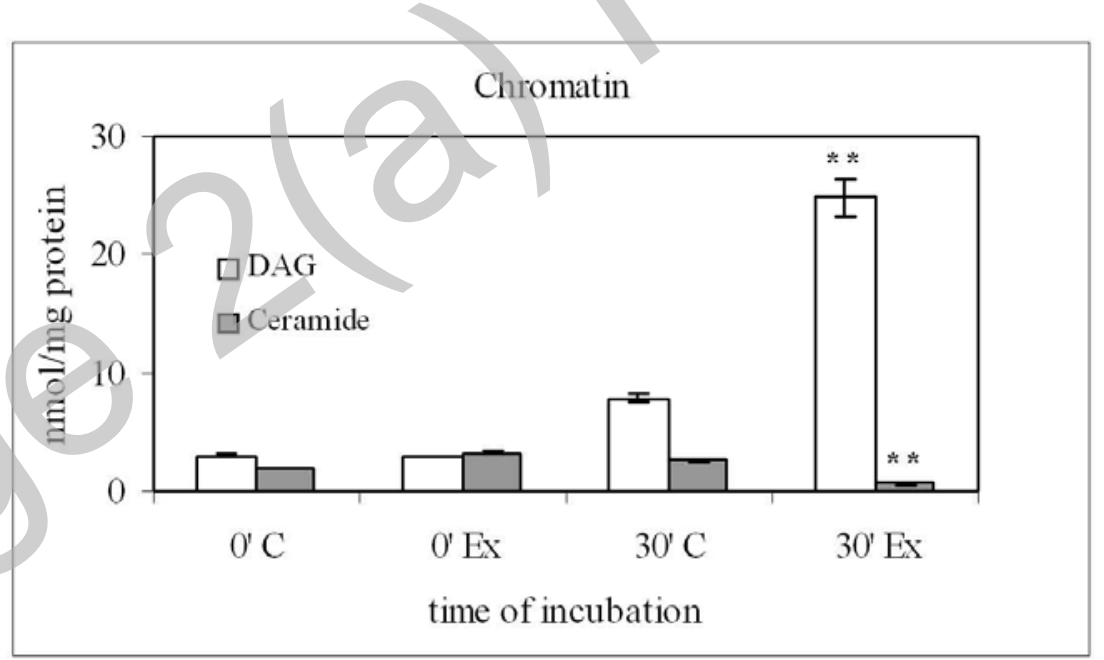

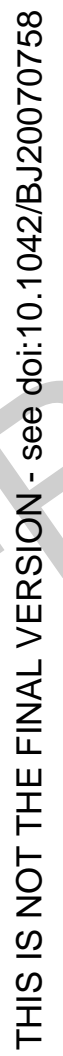

b)

Licenced copy. Copying is not permitted, except with prior permission and as allowed by law. (c) 2007 The Authors Journal compilation (@ 2007 Biochemical Society 


\section{Fig.6}

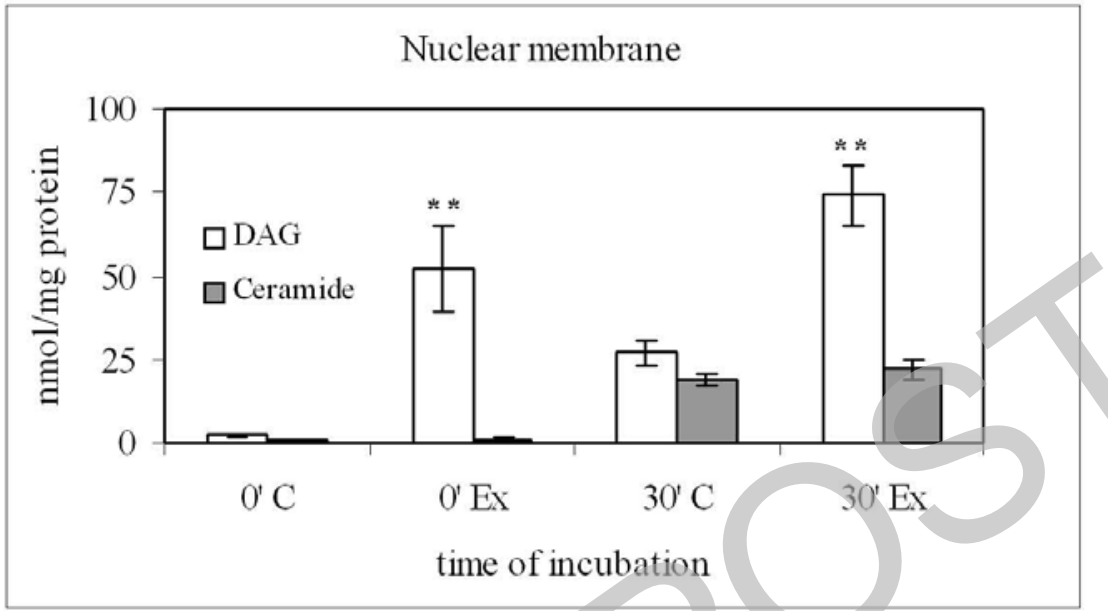

a)

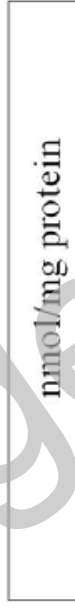

Chromatin

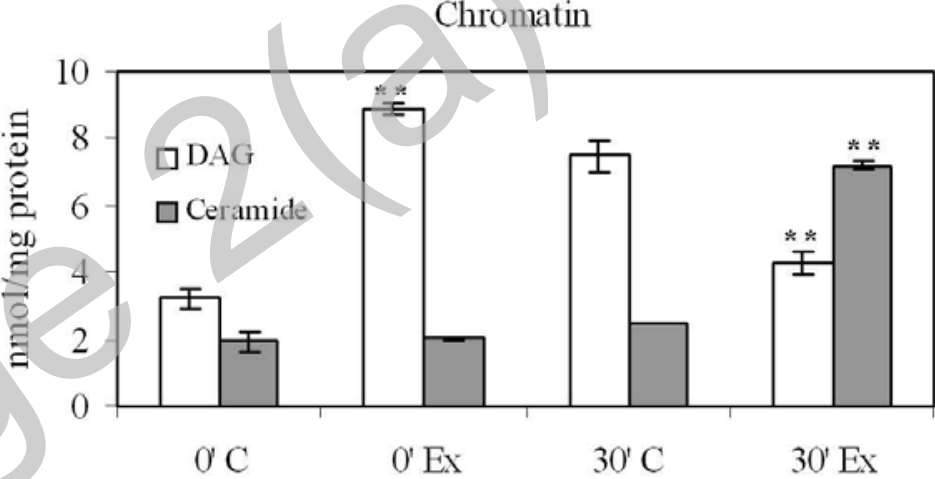

time of incubation

b)

Licenced copy. Copying is not permitted, except with prior permission and as allowed by law. (c) 2007 The Authors Journal compilation (c) 2007 Biochemical Society 
Fig.7

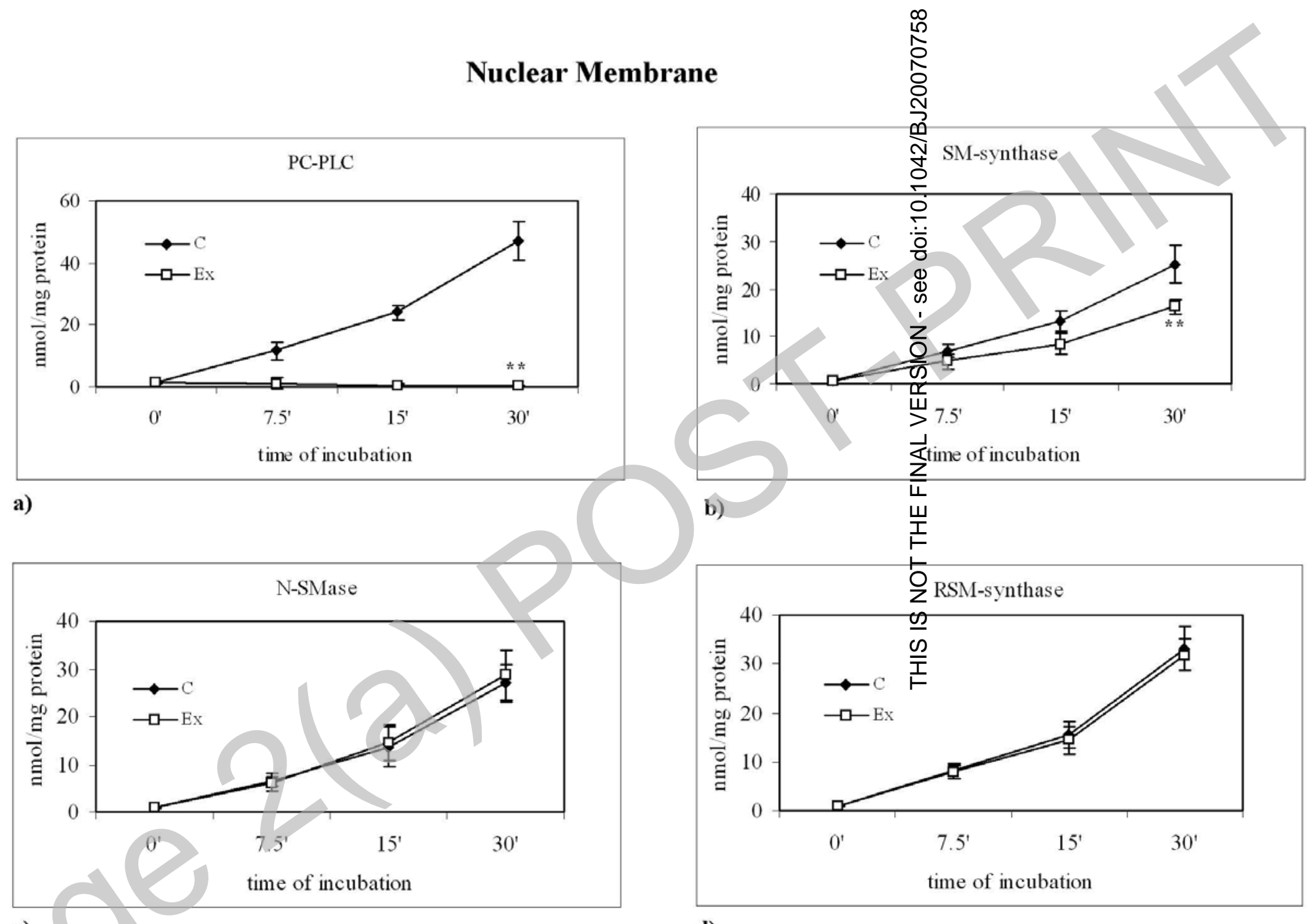

Licenced copy. Copying is not permitted, except with prior permission and as allowed by law. (c) 2007 The Authors Journal compilation (c) 2007 Biochemical Society 


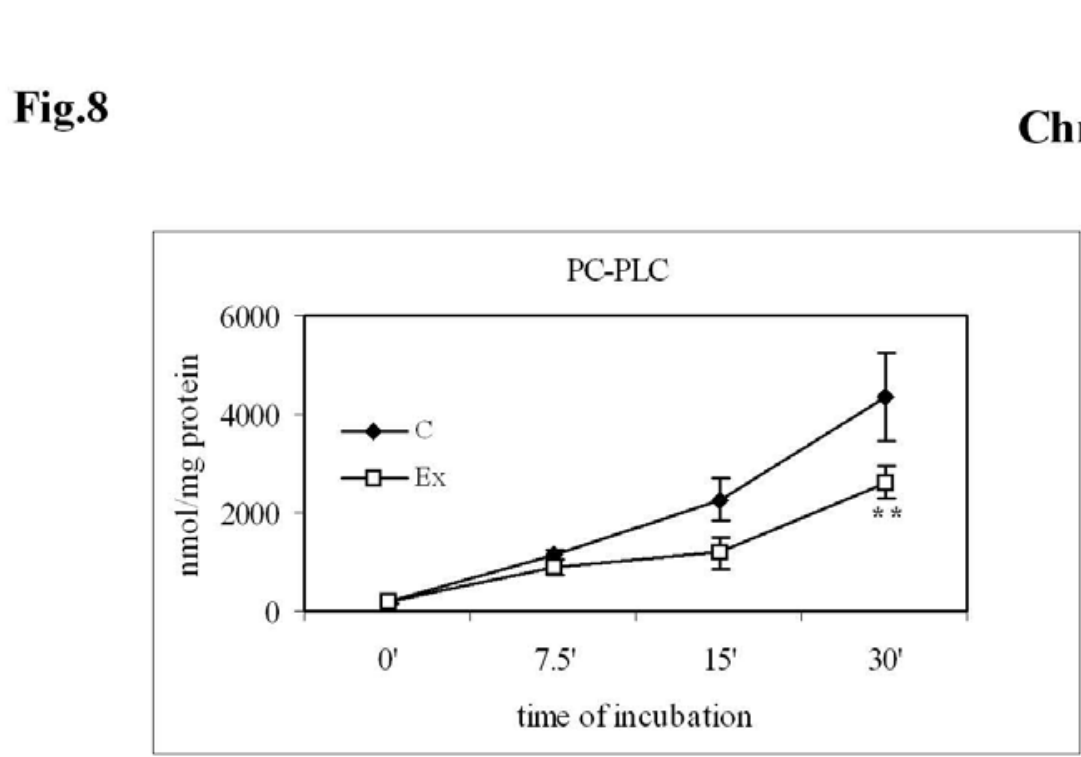

a)

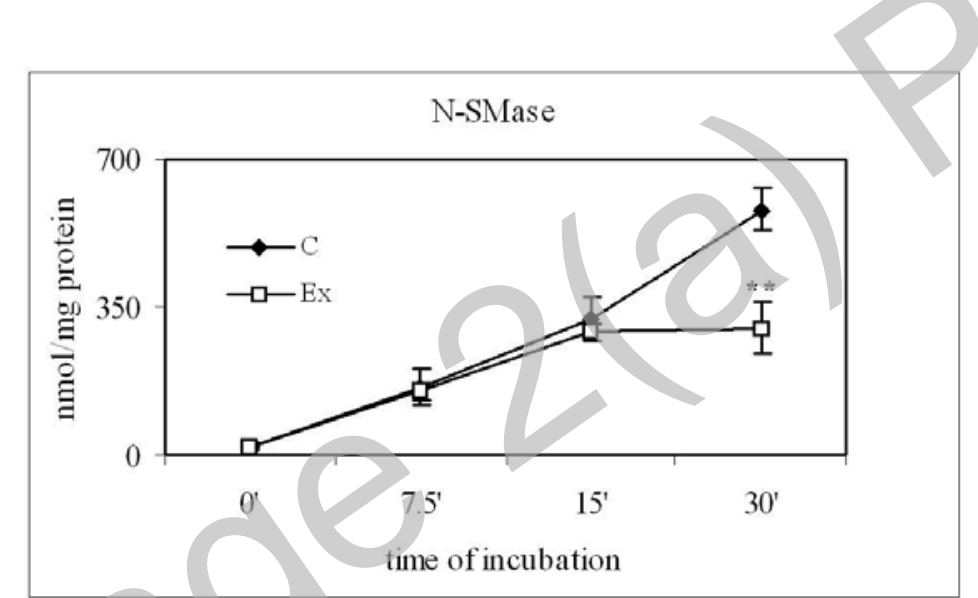

b)

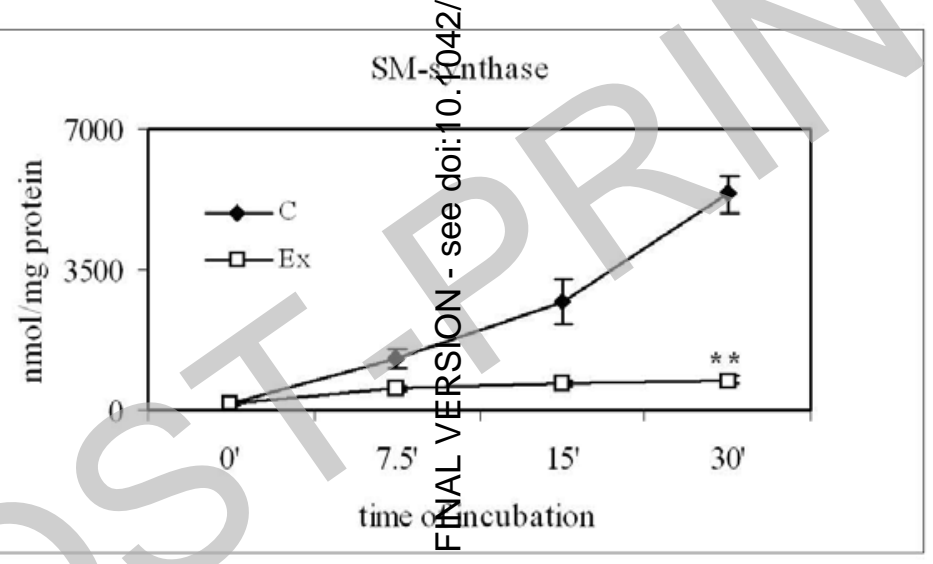

Щ

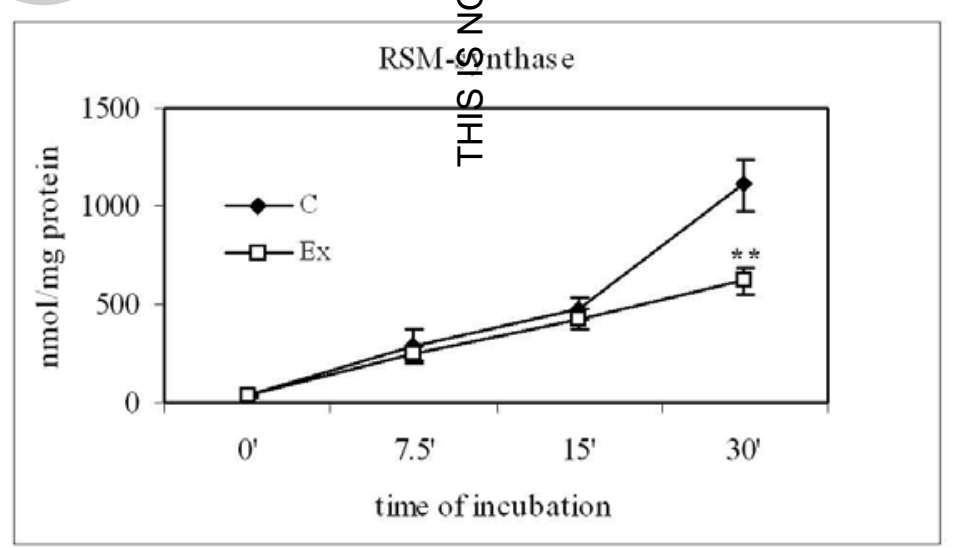

d)

Licenced copy. Copying is not permitted, except with prior permission and as allowed by law. (c) 2007 The Authors Journal compilation (c) 2007 Biochemical Society 
Fig.9

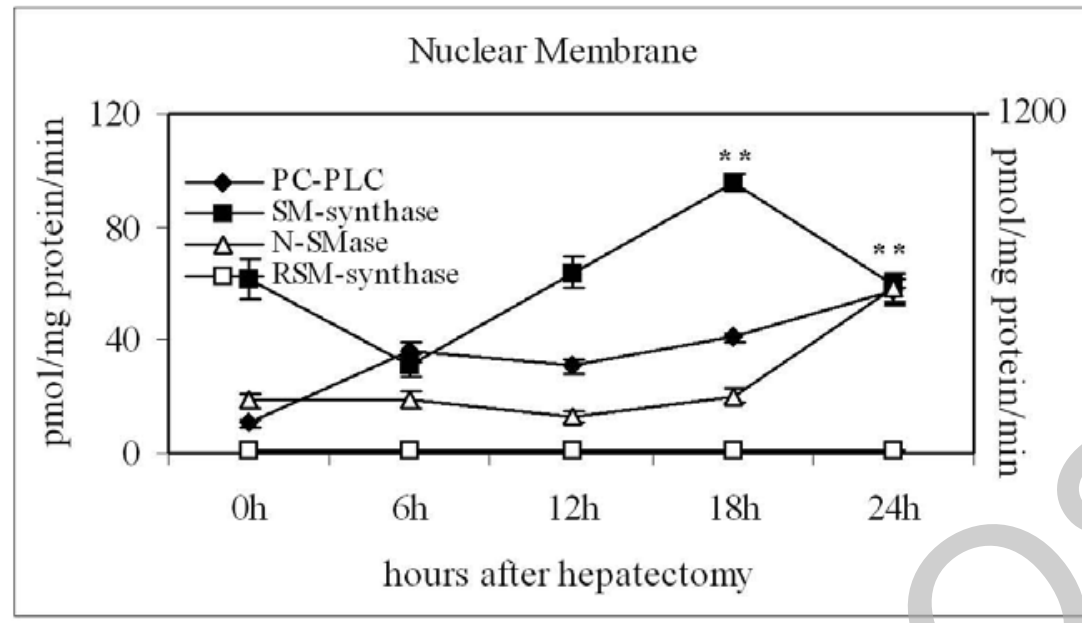

a)

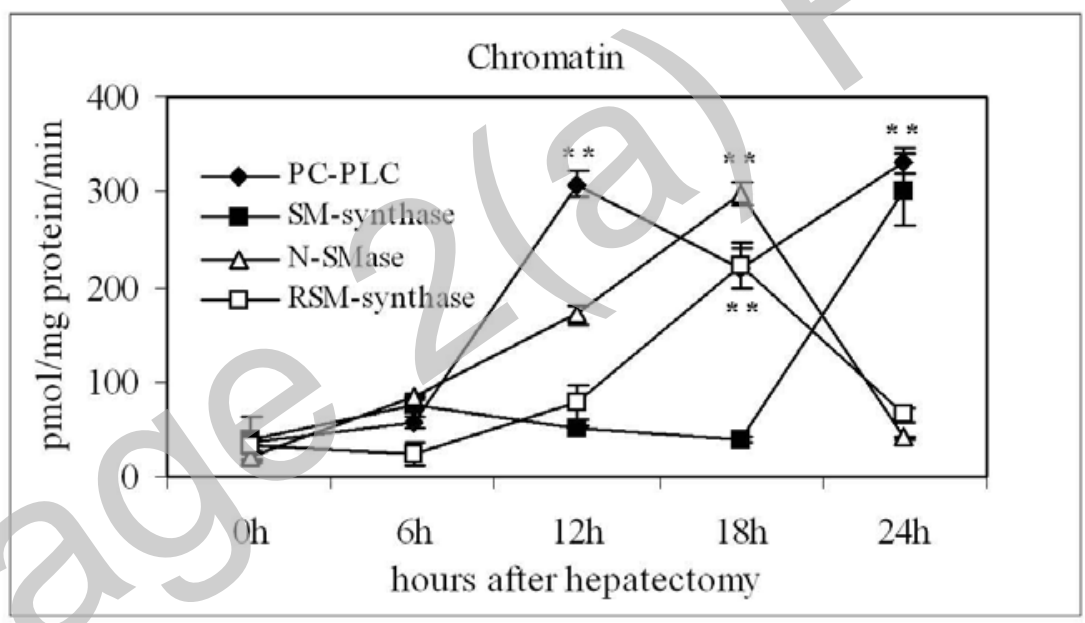

b)

Licenced copy. Copying is not permitted, except with prior permission and as allowed by law. (c) 2007 The Authors Journal compilation (@ 2007 Biochemical Society 